\title{
足趾圧迫力発揮時における下肢筋活動量について
}

\section{Activity of lower extremity muscle during the toe pressuring force action}

\author{
相馬 正之 ${ }^{1)}$, 村田 伸 ${ }^{2)}$, 太田尾 浩 ${ }^{3}$, 甲斐 義浩 ${ }^{2}$ \\ 中江 秀幸 ${ }^{1)}$, 佐藤 洋介 ${ }^{1)}$, 村田 潤 ${ }^{4}$
}

\author{
Masayuki Soma $^{1)}$, Shin Murata ${ }^{2)}$, Hiroshi OTao ${ }^{3)}, Y_{\text {oshihiro Kai }}{ }^{2}$ \\ Hideyuki Nakae $^{1)}$, Yousuke Satou ${ }^{1)}$, Jun Murata ${ }^{4)}$
}

\begin{abstract}
要旨：［目的］本研究は, 足趾圧迫力発揮時の大腿・下腿筋の関与を分析するため, 下肢 筋の筋活動量を測定し，足趾圧迫力との関係を検討した。[対象・方法］健常成人女性18 名を対象とした。足関節底屈, 背屈時および膝関節屈曲, 伸展時の最大随意等尺性収縮の 筋活動量を測定し, 足趾圧迫力発揮時の前脛骨筋, 腓腹筋内側頭, 大腿直筋, 大腿二頭筋 長頭の\%IEMG を算出した。得られた各筋の\%IEMG と足趾圧迫力との関係についてピア ソンの積率相関係数で検討した。[結果] 足趾圧迫力発揮時には, 下腿筋の\%IEMG が19.3 〜 25. 3\%認められた。また，各筋の\% IEMG と足趾圧迫力で求めたピアソンの積率相関係 数は, 前脛骨筋と足趾圧迫力の間に $\mathrm{r}=0.53(\mathrm{p}<0.05)$, 腓腹筋内側頭と足趾圧迫力の間 に $\mathrm{r}=0.51 （ \mathrm{p}<0.05 ）$ との間に有意な正の相関関係が認められた。しかし，大腿直筋と大 腿二頭筋長頭の\%IEMG は，足趾圧迫力と有意な相関は認められなかった。[結語］この ことから足趾圧迫力発揮時に下腿筋群は同時収縮を行い, その筋活動量は足趾圧迫力に反 映されることが示唆された。
\end{abstract}

キーワード：足趾圧迫力, 下肢筋活動量

\begin{abstract}
Purpose] the purpose of this study was to investigate the activity of femoral and crural muscle during the toe pressuring force action, and examine relationship toe pressuring force and femoral and crural muscle. [subjects] subjects were 18 healthy adult females. [method] we compared the normalized integrated electromyogram (\%iemg) of tibial anterior muscle, medial head of gastrocnemius muscle, and soleus muscle among dorsal flexion intermediate position, and plantar flexion. [result] the results showed crural muscles was confirmed 19.3 to $25.3 \%$ iemg of the maximum voluntary contraction. \%iemg of the tibialis anterior muscle and medial head of the gastrocnemius muscle demonstrated a positive correlation with toe pressuring force $(r=0.53$ and $r=0.51$, respectively). [conclusion] these results suggested that crural muscle was co-contracting during the toe pressuring force action, and \% iemg reflected toe pressuring force.
\end{abstract}

Key words: toe pressuring force, activity of lower extremity muscle

\footnotetext{
受付日：2021年 8 月19日，採択日：2021年 9 月15日

1) 東北福祉大学健康科学部リハビリテーション学科

干981-8522 宮城県仙台市青葉区国見 1-8 - 1

TEL : 022-233-3111 FAX : 022-233-3113 E-mail : souma@tfu-mail.tfu.ac.jp

:1-8-1, Kunimi, Aoba-ku, Sendai-city, 981-8522, Japan

TEL:022-233-3111 FAX: 022-233-3113 E-mail: souma@tfu-mail.tfu.ac.jp

2) 京都橘大学健康科学部理学療法学科

3) 西九州大学リハビリテーション学科

4) 長崎大学大学院 医歯薬学総合研究科保健学専攻
} 


\section{I 、はじめに}

近年, 足趾の筋力の指標である足趾把持力は, 測定 が簡便であり， バランス機能,2)や歩行機能3)，転倒リ スク ${ }^{4.5)}$ との間に関連が示されている。足趾把持力は, 足趾にて足趾把持バーを把持し，全足趾を屈曲するこ

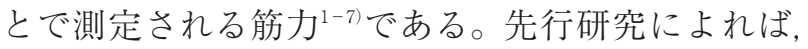
健常高齢者の片脚立位保持時間 ${ }^{1)}$ 健常若年者の Functional reach test（以下, FRT) ${ }^{2)}$, 快適求よび最 大歩行速度 ${ }^{3}$ などの身体機能との関係が認められてい る。また，足趾把持力発揮時の足関節の運動学的解析 や筋活動量に関する報告 ${ }^{6-8)}$ もある。相馬ら ${ }^{6}$ は，足趾 把持力発揮時に足関節が中間位から背屈方向に平均 3 度とわずかな変化であったが，その角度変化と足趾把 持力との間に正相関を認めることを明らかにしている。 さらに, 足趾把持力発揮時の下肢筋活動量については, 大腿筋群との間には関係を認めない7ものの, 前脛骨

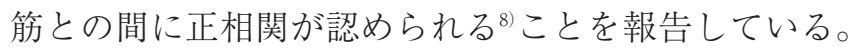
このように足趾把持力については，発揮に影響を及ぼ す要因の解析もなされている。

また，足趾把持力と類似している足趾圧迫力の報告 も散見される ${ }^{9-12)}$ 。足趾圧迫力は, 全足趾を屈曲させ 床を押すことで測定される筋力 ${ }^{9-12}$ であり, 健常若年 者に扔ける前方リーチ動作時の足圧中心移動距離 ${ }^{10} や$ 入院患者の最大歩行速度 ${ }^{11}$ などの身体機能との関連性 が報告されている。このように足趾把持力と足趾圧迫 力は, 反映する身体機能が異なるものの, 身体機能の 評価としていずれも有用年であることが示されている。 しかし，足趾圧迫力については，発揮に影響を及ぼす 要因についての報告はなされていない。足趾圧迫力発 揮に影響を及ぼす要因を検討することは，足趾圧迫力 を解析するためにも重要と考えられる。

そこで本研究では, 足趾圧迫力発揮時の下肢筋の筋 活動量を測定し，足趾圧迫力との関倸を検討した。

\section{II. 対象と方法}

\section{1. 対 象}

対象は健常成人女性 18 名とし，いずれも下肢に整形 外科的疾患や疼痛などの既往はみられなかった。被験 者の年齢は平均 $20.9 \pm 0.5$ 歳, 身長は平均 $162.2 \pm 6.7$ $\mathrm{cm}$, 体重は平均 $52.2 \pm 4.9 \mathrm{~kg}$ であった。被験者には 研究の趣旨と内容, 得られたデー夕は研究の目的以外 には使用しないこと，および個人情報の漏洩に注意す ることについて説明し，十分に理解を得たうえで協力 を求めた。また, 研究への参加は自由意志であり, 被
験者にならなくても不利益にならないことを口答と書 面で説明し, 同意を得て研究を開始した。なお，本研 究は, 所属機関の研究倫理委員会の承認 (RS160706) を受けて実施した。

\section{2. 方 法}

測定項目は, 利き足の足趾圧迫力と表面筋電図 (Electronmyogram：以下, EMG) から得られる足 趾圧迫力発揮時の大腿直筋, 大腿二頭筋長頭, 前脛骨 筋, 腓腹筋内側頭の筋活動量とし, 足趾圧迫力計と EMG を同期させ測定した。

足趾圧迫力の測定は, 足趾押力測定器 13 ) (竹井機器 工業）を用いた。本機器は，足趾全体で下方向に押す 力を測定できる機器である。測定肢位は端座位とし, 体幹垂直位，股関節抢よび膝関節 90 度屈曲位，足関節 中間位として足関節固定ベルトを用い，測定した。足 趾の押す力を測定するフォースプレートには，母趾球 などが触れないように留意し, 足趾のみがセンサー部 分に乗るように測定器の位置を調整して計測した（図 $1)$ 。足趾圧迫力の測定時間は 5 秒間とした。足趾が

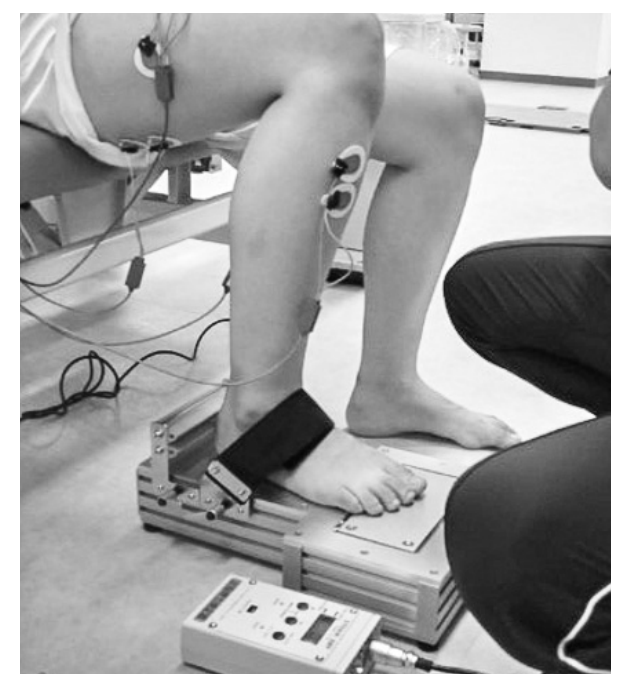

图 1 足趾と足趾押力測定器の位置関係

フォースプレートに力を加える際には, 体幹を前屈し て足趾に体重を荷重したり，足関節を底屈して力を加 えたり，足趾の筋力以外の影響が測定值に反映されな いように注意した。測定は, 事前に数回の練習をした 後に 2 回測定し，その最大值を解析に用いた。

大腿直筋, 大腿二頭筋長頭, 前脛骨筋と腓腹筋内側 頭の最大随意等尺性収縮 (maximum voluntary contraction:MVC) の筋活動量を測定するため, 被験者 に股・膝関節 90 度, 足関節中間位とした椅子座位をと らせ, 検者が膝関節伸展, 屈曲方向および足関節背屈, 
底屈方向に抵抗を加え, その際の最大の膝関節伸展筋 および屈曲筋, 足関節背屈筋および底屈筋の筋活動量 を測定した。

筋活動量の測定には表面筋電計（Noraxon 社製, TeleMyoG 2 ）を用い, サンプリング周波数は $1000 \mathrm{~Hz}$ とした。測定筋は, 大腿直筋, 大腿二頭筋長頭, 前脛 骨筋および腓腹筋内側頭とし, 最大足圧迫力発揮時の 筋活動量を測定した。各筋の電極貼付部位は, Perotto の記述 ${ }^{14)}$ に準じて貼付し，電極間距離は $2 \mathrm{~cm}$ とした。 すなわち, 大腿直筋では膝蓋骨上縁と上前腸骨棘を結 んだ中点に，大腿二頭筋長頭では腓骨頭と坐骨結節を 結んだ中点に, 前脛骨筋では脛骨粗面より 4 横指遠位 部で脛骨稜より 1 横指外側に, 腓腹筋内側頭では膝窩 皮線より 5 横指遠位部で内側の筋腹にそれぞれ貼付し た。筋電信号の導出には, 解析ソフト (Noraxson 社 製，MyoResearch XP）を用い, 20-500Hz の带域通 過フィルターを適応して, あらかじめ筋電信号からノ イズを除去した。導出された筋電信号は，全波整流処 理を行ったのち, 最大足趾圧迫力発揮 3 秒間の中間 1 秒間の積分筋電 (Integrated Electronmyogram: IEMG）を求めた。得られた IEMG は, 各筋の最大随 意等尺性収縮（Maximum Voluntary contraction: MVC) の值を基準に正規化（\%IEMG）した。

統計処理は, 各筋の\% IEMG と足趾圧迫力の関連性 にはピアソンの積率相関係数を用いて検討し, 有意水 準を 5 \%とした（IBM,SPSS ver26.0)。

\section{III. 結 果}

足趾圧迫力と足趾圧迫力発揮時の下肢 4 筋である大 腿直筋, 大腿二頭筋長頭, 前脛骨笳抢よび腓腹筋内側 頭の各\%IEMG を表 1 に示した。足趾圧迫力発揮時に

表 1 足趾圧迫力発揮時の実側值

\begin{tabular}{lc}
\hline 足趾圧迫力 $(\mathrm{kg})$ & $10.3 \pm 2.9$ \\
前脛骨筋 $\% \operatorname{IEMG}(\%)$ & $25.2 \pm 18.9$ \\
腓腹筋内側頭\% IEMG (\%) & $19.3 \pm 15.0$ \\
大腿直筋 $\% \operatorname{IEMG~}(\%)$ & $8.3 \pm 8.5$ \\
大腿二頭筋長頭\% IEMG $(\%)$ & $8.4 \pm 6.0$ \\
\hline
\end{tabular}

表 2 足趾圧迫力と各筋の \% IEMGの 相関関係について $(\mathrm{n}=18)$

\begin{tabular}{llc}
\hline & & 相関係数 $(\mathrm{r})$ \\
\hline \multirow{2}{*}{ 足趾圧迫力 } & 前脛骨筋 & $0.53^{*}$ \\
& 腓腹筋内側頭 & $0.51^{*}$ \\
& 大腿直筋 & 0.34 \\
& 大腿二頭筋長頭 & 0.44 \\
\hline
\end{tabular}

$: p<0.05$
おいて下肢 4 筋の\%IEMG は8. 3〜25.2\%の範囲の活 動量であった。また，足趾圧迫力と各筋の\%IEMGで 求めたピアソンの積率相関係数は, 前脛骨筋と足趾圧 迫力の間に $\mathrm{r}=0.53(\mathrm{p}<0.05)$, 腓腹筋内側頭と足趾 圧迫力の間に $\mathrm{r}=0.51 \quad(\mathrm{p}<0.05)$ と有意な正の相関関 係が認められた。しかし, 大腿直筋と大腿二頭筋長頭 の\%IEMG は，足趾圧迫力と有意な相関は認められな かった。

\section{IV. 考 察}

本研究は, 足趾圧迫力発揮時の下肢筋の筋活動量を 測定し，足趾圧迫力との関係を検討した。得られた足 趾圧迫力は平均 $10.3 \mathrm{~kg}$ であり，\%IEMGは大腿筋が 8.3〜8.4\%, 下腿筋が19.3〜25.2\%であった。また, 足趾圧迫力と下肢 4 筋との関連性については, 前脛骨 筋および腓腹筋内側頭と足趾圧迫力の間に有意な正の 相関関係が認められた。こられのことから, 足趾圧迫 力発揮時に下腿筋群は同時収縮を行い, その筋活動量 は足趾圧迫力に反映されることが示唆された。

足趾圧迫力と足趾圧迫力発揮時の前脛骨筋および腓 腹筋内側頭の筋活動量との間に有意な相関が認められ た要因について以下に推察する。末梢である足趾の筋 力を効率よく発揮するには, 足関節の安定化作用が要 求される。足趾圧迫力を出力する足趾屈筋群は, 足関 節底屈の補助筋の作用も兼ねる ${ }^{15)}$ ことから, 足趾圧迫 力発揮時には足関節の底屈が生じやすくなる。その足 関節底屈作用を防止するため, 拮抗筋である前脛骨筋 が収縮する。この前脛骨筋の作用によって，足関節を 中間位に固定し, 足趾圧迫力を効率よく発揮している と考えられる。この前脛骨筋の作用の影響として, 足 趾圧迫力発揮時に腓腹筋内側頭も同時収縮をすること で足関節を固定する役割を果たしているものと考えら れる。足関節を構成する距腿関節は, 距骨滑車と脛骨 の下関節面，その両側に続く脛骨の内果関節面および 外果関節面 (果間関節窩) により形成され, 距骨滑車 が前方よりも後方の幅が広いため, 底屈位では距骨滑 車と果間関節窩の接触が弱まり, 関節に遊びが生じる。 一方, 中間位から背屈位では, 距腿滑車は果間関節窩 にはまり込むために関節の遊びが生じずに安定性が得 られる16.17)。このことから, 足趾圧迫力発揮時に前脛 骨筋の強い収縮が得られるほど, 距腿関節の解剖学的 構造により, 足関節の安定化が得られ, 効率よく足趾 圧迫力を発揮できることが推測された。

一方，大腿四頭筋と大腿二頭筋長頭の $\%$ IEMG と足 
趾圧迫力との間に有意な相関が認められなかった。本 研究に㧍いては大腿筋の\%IEMG が8. 3〜8.4\%認めら れている。足趾圧迫力揮時には, 膝関節の安定性も要 求される。そのため, 膝関節の周囲筋である大腿直筋 や大腿二頭筋などは, 同時収縮を行うことで膝関節の 安定性に寄与していると考えられた。しかし, 足趾圧 迫力を構成すると考えられる足趾屈筋群は下腿部や足 部に起始・停止を持つ筋群である。そのため, 足趾よ り遠位にある大腿部の筋群とは関係が認められなかっ たと考えられた。

本研究結果からは, 足趾圧迫力を測定する際に前脛 骨筋㧍よび腓腹筋内側頭といった下腿筋活動量が影響 することが示された。そのため, 足趾圧迫力の低下が 単に足趾屈筋群の筋力低下のみならず, 下腿筋群の機 能低下によっても生じる可能性が考えられた。本研究 の限界として, 皮膚抵抗の影響やアーチファクト, 近 傍にある筋からのクロストークの影響といった表面筋 電図特有の問題点がある。また, 被験者を健常若年女 性に限定していた為，本結果が幅広い年齢層に該当す るとは限らない。今後は, これら諸問題への対応を考 慮した上で，高齢者や男性などを対象に同様の結果が 得られるかどうかを検証する必要がある。

\section{引用文献}

1) 相馬正之, 五十嵐健文, 工藤渉 - 他 : 足指把持力の Functional reach test および最大一歩幅の関係性について. 東北 理学療法学, 2013, 25: 14-18.

2)村田伸, 太田尾浩, 大山美智江 - 他 : 女性高齢者の片足立 ち保持時間に関連する要因。日本在宅ケア学会誌, 2009, 13 (1) : 71-77.

3)相馬正之, 五十嵐健文, 工藤涉・他 : 若年者に扔ける足指 把持力と歩行能力の関係について. 東北理学療法 学, 2012, $24: 54-58$.

4) 村田伸, 忽那龍雄 : 在宅障害高齢者に対する転倒予防対策足把持力トレーニング. 日本在宅ケア学会誌, 2004, 7(2)： 67-74.

5)村田伸, 忽那龍雄 : 在宅障害者の足把持力と転倒との関連 性. 国立大学理学療法士学会誌, 2003, 24:8-13.

6) Souma M, Murata S, Kai Y, et al.: Kinematic analysis during toe-gripping strength exertion: angular changes in the ankle joint and leg muscle activities. J. Phys. Ther. Sci, 2015, 27 (6) : 1957-1960.

7) Soma M, Murata S, Kai Y, et al.: Comparison of toe grip strength and muscle activities during maximal toe grip strength exertion according to the presence/absence of an ankle immobilization belt. J. Phys. Ther. Sci, 2015, 27(10) : 3081-3084.

8)相馬正之, 村田伸, 甲斐義浩 - 他 : 足指把持力発揮時にお ける下腿筋の筋活動. 理学療法科学, 28(4)：491-494, 2013.
9)竹井和人, 村田伸, 甲斐義浩 : 足趾機能と静的・動的バラ ンスとの関連 - 内容的妥当性の検討 - . 西九州リハビリテー ション研究, 2009, 2 : 13-19.

10)辻野綾子, 田中則子：足趾圧迫力と前方リーチ動作時の足 圧中心位置の関係. 理学療法科学, 2008, 22(2) : 245-248.

11) 南條恵悟, 長澤弘, 千葉公太・他 : 歩行速度と下肢筋力の 違いは足趾圧力と歩行速度・バランス能力の寒冷性に影響 するのか？. 理学療法科学, 2016, 31(1) : 151-155.

12)釜崎大志郎, 大田尾浩, 八谷瑞紀 ·他 : 要介護高齢者の足 指把持力および足趾圧迫力と身体機能との関連 - 足指機能 評価の有用性の検証 - . 理学療法さが, 2018, 4(1) : 31-36.

13) 竹井機器工業株式会社, 産学連携特注品 - 開発品一覧, 足 指押力測定器 (http://www.takei-si.co.jp/cooperation/special.html), 2021年 8 月19日.

14) Aldo O. Perotto, 柏森良二（訳）：筋電図のための解剖ガ イドー四肢・体幹－第 3 版．西村書店，東京, 2007, 140-155.

15) 中村隆一 - 斎藤宏: 基礎運動学第 6 版. 医歯薬出版, 東 京, 2008, 76-78.

16) 壇順司 : 足関節の機能解剖 - 人体解剖から紐解く足関節の 機能一。理学療法学, 2013, 40(4) : 326-330.

17) Donald A.Neumann 嶋田智明監訳 : 筋骨格系のキネシオロ ジー (第 1 版第 3 刷), 医歯薬出版会社, 東京, $2006 ; 234$ 235, 636-641. 